\title{
Whole-genome sequencing and the physician
}

Citation for published version (APA):

Thorogood, A., Knoppers, B. M., Dondorp, W. J., \& de Wert, G. M. W. R. (2012). Whole-genome sequencing and the physician. Clinical Genetics, 81(6), 511-513. https://doi.org/10.1111/j.13990004.2012.01868.x

Document status and date:

Published: 01/06/2012

DOI:

10.1111/j.1399-0004.2012.01868.x

Document Version:

Publisher's PDF, also known as Version of record

Document license:

Taverne

Please check the document version of this publication:

- A submitted manuscript is the version of the article upon submission and before peer-review. There can be important differences between the submitted version and the official published version of record.

People interested in the research are advised to contact the author for the final version of the publication, or visit the DOI to the publisher's website.

- The final author version and the galley proof are versions of the publication after peer review.

- The final published version features the final layout of the paper including the volume, issue and page numbers.

Link to publication

\footnotetext{
General rights rights.

- You may freely distribute the URL identifying the publication in the public portal. please follow below link for the End User Agreement:

www.umlib.nl/taverne-license

Take down policy

If you believe that this document breaches copyright please contact us at:

repository@maastrichtuniversity.nl

providing details and we will investigate your claim.
}

Copyright and moral rights for the publications made accessible in the public portal are retained by the authors and/or other copyright owners and it is a condition of accessing publications that users recognise and abide by the legal requirements associated with these

- Users may download and print one copy of any publication from the public portal for the purpose of private study or research.

- You may not further distribute the material or use it for any profit-making activity or commercial gain

If the publication is distributed under the terms of Article $25 \mathrm{fa}$ of the Dutch Copyright Act, indicated by the "Taverne" license above, 


\section{Commentary}

\section{Whole-genome sequencing and the physician}

Whole-genome sequencing (WGS) technologies analyze genetic variation across the entire range of human genetic material (1-4). With rapidly decreasing costs, WGS may be used for both targeted diagnostic testing (5) and genome-wide searches for the mutations that underlie unexplained disorders $(3,6,7)$. It is currently recommended that genetic testing should be as targeted as possible to solve a particular clinical problem (8). If targeted testing fails however, physicians may justifiably 'trawl' through the genome for mutations that underlie complex cases of multiple congenital malformation or unexplained intellectual disability (3). The introduction of untargeted WGS for diagnostic testing in the clinic has great potential to improve the range and efficacy of genetic testing. With reference to international ethical guidelines, this article explores how WGS impacts four traditional obligations of physicians: the duty to obtain informed consent, the duty to treat, the duty to follow-up and the duty of professional secrecy.

\section{The duty to obtain informed consent}

A physician must obtain free and enlightened consent from a patient before undertaking medical care or research $(9,10)$. The plethora of 'incidental' findings that accompany WGS pose a challenge to informed consent. Little guidance exists for physicians on whether, or how, these findings should be communicated to patients (11). Guidelines for biomedical research, such as the Canadian Tri-Council Policy Statement, suggest that a plan for the ethical return of incidental findings should be included in informed consent for WGS diagnostics (12). In research, informed consent increasingly relies on 'broad consent' models that outline the categories of findings that will be returned (13). The National Cancer Institute (NCI) 'smart filter', for example, developed in the biobanking context, gives a list of criteria for returnable results including analytical validity, clinical significance, and clinical actionability (14). Patients, however, may have fewer choices in their consent to testing than research participants. In the clinical context, Berg et al. suggest that vast incidental findings could be organized in 'a clinically oriented manner to facilitate shared decision making by patients and clinicians' $(6,15)$. They suggest a binning system in which clinically actionable results are categorically reported, clinically valid but not directly actionable results are returned depending on patient preference, and results of unknown or no clinical significance are not returned.
This sketch of a solution for incidental findings in the clinical context is far from complete. As informed consent attempts to address more complex issues, it may become prohibitively expensive, or 'arduous, if not impossible, to inform patients ... without inducing information overload and therewith foregoing the actual aim of informed consent' (16). The research context however, may provide useful guidance to keep these problems in check.

\section{The duty to treat}

The duty to treat is the most evident duty of physicians (17). In order to provide appropriate treatment, they must stay abreast with medical science (18). Faced with the rapidly evolving technology and knowledge base of WGS, the standard of knowledge to bring to the interpretation of WGS results is unclear. Fear of liability for the negligent interpretation of results is not unfounded $(19,20)$. There is a growing consensus in the United States that the standard of care expected of physicians is 'both the duty to identify patients' genetic concerns and to refer them to appropriate resources' (21). As WGS technology becomes more prevalent in the clinic, efforts need to be made to clarify the extent to which they are expected to understand genomic information, and systemic changes to the health system need to be introduced to help them cope with these expectations $(21,22)$.

\section{The duty to follow-up}

Physicians are required to provide medical follow-up after an examination or treatment $(12,19)$. On the one hand, physicians may risk liability under negligence if they ignore unvalidated genetic findings. On the other hand, they may order a battery of alternative, targeted tests to confirm WGS tests that expose patients to iatrogenic harms (23) and place further strain on already limited primary health care resources (24).

Does the duty to follow-up encompass the re-contact of patients when the meaning of past WGS test results changes? (25) Currently, in the United States, UK and Canada, physicians are not legally responsible for re-contact, and it is up to the patient to initiate reevaluation $(26,27)$. Imposing this duty on physicians would be problematic for other reasons. First, it will be difficult to define or delimit the scope of this duty when a large amount of genomic material is potentially stored in a patient's health record, and susceptible to evolving 


\section{Commentary}

interpretation. Second, the patient's 'right not to know' about genetic health risks may be difficult to protect even if patients were to determine how their genomic information is filtered.

\section{Duty to maintain professional secrecy}

Patient information must be kept confidential in order to maintain trust, autonomy, and respect in the doctorpatient relationship. With the development of WGS, there is increasing tension between the duty of professional secrecy, and a physician's ethical duty toward relatives of a patient to inform them of risks revealed by genetic testing. On the one hand, genetic information has implications for a patient's autonomy and private life, and therefore merits a high level of protection (28). On the other hand, the vast incidental findings of WGS increase the likelihood of other significant findings having health implications for a patient's biological relatives. In addition, mutations having no direct health impact may have serious implications for the reproductive decision making of family members (29).

Legally, breaching confidentiality to warn a third party is only possible under strict conditions; it generally requires, inter alia, a threat of a serious and imminent harm $(11,30)$.WGS tends to reveal common, multifactorial risks, or rare, mostly untreatable conditions, and is considered unlikely to meet these requirements (31). Therefore, if patients refuse to share test results with at-risk relatives, physicians will not be expected, or even allowed, to disclose the information themselves (31).

The primacy of professional secrecy, however, should not detract attention from the emerging ethical duties that physicians have toward at-risk relatives. Physicians may increasingly be expected to ensure that pertinent WGS results reach family members $(29,32)$. As these expectations crystallize into standards of care, physicians may be legally required to adequately direct patients to share WGS results with at-risk relatives, request permission from patients to disclose the information directly, or perhaps even make efforts to communicate with family members in a way that does not breach patient confidentiality (29).

A final consideration that concerns the sharing of test results with family members is the 'right not to know'. Some relatives may value genetic risk information in helping to plan for the future, while others would prefer not to know about it at all. This may be especially true for information on untreatable, late-onset conditions (33).

\section{Conclusion}

This paper has outlined how WGS increases uncertainty for the obligations physicians owe their patients. The potential for unintended but significant health findings complicates informed consent. Rapidly evolving technologies leave physicians uncertain about the standard of care required to employ or interpret WGS. Physicians are left faced with a precarious choice between ignoring results of uncertain validity and costly, possibly risky, follow-up testing. The familial nature of genetic information places strain on the duty of confidentiality. WGS is also becoming available through direct-to-consumer (DTC) genetic testing companies. Novel ethical issues may also arise as patients approach their family doctors for interpretation of their DTC test results (34-36). In any event, the legal and ethical uncertainties of WGS must be addressed before WGS technologies can be successfully implemented in the clinic.

\section{Acknowledgements}

W. J. D. and G. M. W. R. W. would like to thank the Dutch Centre for Society and Genomics, funded by The Netherlands Genomics Initiative (NGI, project number: 70.1.070) for supporting their work toward this paper. B. M. K. acknowledges the Canada Research Chair in Law and Medicine, the Quebec Network of Applied Genetic Medicine (RMGA) of the Fonds de la recherche en santé du Québec (FRSQ) and the NGI.

\section{Conflict of interest}

The authors have no conflicts of interest.

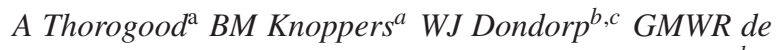
Wert $^{b, c}$

${ }^{\mathrm{a}}$ Centre of Genomics \& Policy, Faculty of Medicine, Department of Human Genetics, McGill University, Montreal, QC H3A 1A1, Canada,

${ }^{b}$ Department of Health, Ethics \& Society, Maastricht University, 6200 MD Maastricht, The Netherlands, and

${ }^{\mathrm{c}}$ Research Schools GROW and CAPHRI, Maastricht University, 6200 MD Maastricht, The Netherlands

\section{References}

1. Foundation for Genomics and Population Health, Next steps in the sequence, the implications of whole genome sequencing for health in the UK. Cambridge, MA: PHG Foundation, 2011.

2. Feero WG, Guttmacher AE, Collins FS. Genomic medicine - an updated primer. N Engl J Med 2010: 362 (21): 2001-2011.

3. Poot M, Hochstenbach R. A three-step work flow procedure for the interpretation of array-based comparative genome hybridization results in patients with idiopathic mental retardation and congenital anomalies. Genet Med 2010: 12 (8): 478-485.

4. Tucker T, Marra M, Friedman JM. Massively parallel sequencing: the next big thing in genetic medicine. Am J Hum Genet 2009: 85 (2): $142-154$.

5. Burke W, Tarini B, Press NA, Evans JP. Genetic screening. Epidemiol Rev 2011: 33 (1): 148-164.

6. Dondorp WJ, de Wert GM. The 'thousand-dollar genome': an ethical exploration, Monitoring Report Ethics and Health, 2010/2. The Hague: Centre for Ethics and Health, 2010.

7. Worthey EA, Mayer AN, Syverson GD et al. Making a definitive diagnosis: successful clinical application of whole exome sequencing in a child with intractable inflammatory bowel disease. Genet Med 2011: 13: $255-262$.

8. Mayer AN, Dimmock DP, Arca MJ et al. A timely arrival for genomic medicine. Genet Med 2011: 13 (3): 195-196.

9. World Medical Association. Medical ethics manual, Ferney-Voltaire Cedex. France: World Medical Association, 2009.

10. Canadian Medical Association. Code of ethics, update. Ottawa, Canada: Canadian Medical Association, 2004. 
Commentary

11. Knoppers BM, Lévesque E. Return of research results: how should research results be handled? J Law Med Ethics 2011: 39 (4): 574-639.

12. Canadian Institutes of Health Research (CIHR), Natural Sciences and Engineering Research Council of Canada, Social Sciences and Humanities Research Council of Canada, Tri-Council Policy Statement. Ottawa, Canada: Ethical Conduct for Research Involving Humans, 2010.

13. Wallace S, Lazor S, Knoppers BM. Consent and population genomics: the creation of generic tools. IRB 2009: 31 (2): 15-20.

14. National Cancer Institute. Workshop Summary: Workshop on the Release of Research Results to Participants in Biospecimen Studies, Bethesda, MD, 8-9 July 2010.

15. Berg JS, Khoury MJ, Evans JP. Deploying whole genome sequencing in clinical practice and public health: meeting the challenge one bin at a time. Genet Med 2011: 13 (6): 499-504.

16. Bunnik E, Schermer M, Janssens AC. Personal genome testing: test characteristics to clarify the discourse on ethical, legal and societal issues. BMC Med Ethics 2011: 12 (11): 1-13.

17. American Medical Association. Code of ethics. Chicago, IL: American Medical Association, 2010-2011.

18. Downie J, Caulfield T, Flood C. Canadian health law and policy, 3rd edn. Markham: LexisNexis, 2007.

19. Phillips v United States, 566 F Suppl 1 (1981).

20. Marchant GE, Campos-Outcalt DE, Lindor RA. Physician liability: the next big thing for personalized medicine? Pers Med 2011: 8 (4): 457.

21. Kohane IS, Masys DR, Altman RB. The incidentalome: a threat to genomic medicine. JAMA 2006: 296 (2): 212-215.

22. Grosse SD, Khoury MJ. What is the clinical utility of genetic testing? Genet Med 2006: 8 (7): 448-450.

23. Kuehn BM. Scientists see promise and challenges in translating genomics to the clinic. JAMA 2011: 305 (13): 1285-1286.

24. McGuire AL. An unwelcome side effect of direct-to-consumer personal genome testing. JAMA 2008: 300 (22): 2669-2671.
25. Pyeritz RE. The coming explosion in genetic testing - is there a duty to recontact? N Engl J Med 2011: 365: 1367-1369.

26. Knoppers BM. Duty to recontact: a legal harbinger? Am J Med Genet 2001: 103 (4): 277.

27. Hunter AGW, Sharpe N, Mullen M, Meschino WS. Ethical, legal, and practical concerns about recontacting patients to inform them of new information: the case in medical genetics. Am J Med Genet 2001: 103 265-276.

28. Flanagan WF. Genetic data and medical confidentiality. Health Law J 1995: 3: 269-288.

29. Watters $v$ White, Quebec Court of Appeal QCCA 257 (2012).

30. American Society of Human Genetics. ASHG statement: professional disclosure of familial genetic information. Am J Hum Genet 1998: 62: 474-483.

31. Lacroix M, Nycum G, Godard B, Knoppers BM. Should physicians warn patients' relatives of genetic risks? CMAJ 2008: 178 (5): 593-595.

32. Safer v Estate of Pack, 677 A 2d, NJ Super Ct App Div (1996).

33. Andorno R. The right not to know: an autonomy based approach. J Med Ethics 2004: 30: 435-439.

Correspondence:

Adrian Thorogood

Centre of Genomics \& Policy

Faculty of Medicine

Department of Human Genetics

McGill University

740 Av. Dr. Penfield

Montreal

QC H3A 1A1

Canada

Tel.: +514 398 8155;

fax: +514 398 8954;

e-mail: adrian.thorogood@mail.mcgill.ca 